\title{
Chemical Composition, Antibacterial Activity of the Essential Oil from Roots of Radix aucklandiae against Selected Food-Borne Pathogens
}

\author{
Jinxiu Liu, Defeng Huang, Donglin Hao, Qingping $\mathrm{Hu}^{*}$ \\ College of Life Sciences, Shanxi Normal University, Linfen City, China \\ Email:
}

Received 6 September 2014; revised 22 October 2014; accepted 15 November 2014

Copyright @ 2014 by authors and Scientific Research Publishing Inc.

This work is licensed under the Creative Commons Attribution International License (CC BY). http://creativecommons.org/licenses/by/4.0/

(c) (i) Open Access

\begin{abstract}
Radix aucklandiae from Yunnan Province in China is a significant medicinal plant. In the present study, the essential oil composition from Radix aucklandiae roots was investigated by gas chromatography-mass spectrometry (GC-MS). A total of 23 compounds representing $57.95 \%$ of the essential oil were tentatively identified. The main constituents were eremanthin $(12.74 \%)$, $d$-Guaiene $(6.26 \%), \zeta$-Himachalene $(6.16 \%)$ and l-Caryophyllene $(4.84 \%)$. The minimum inhibitory concentration (MIC) and minimum bactericidal concentration (MBC) of the essential oil from $R$. aucklandiae were evaluated against three Gram-positive bacteria (Staphylococcus aureus, Staphylococcus albus and Bacillus subtilis) three Gram-negative bacteria (Salmonella typhimurium, Escherichia coli and Shigella dysenteriae). Results revealed that the essential oil exhibited significant in vitro antimicrobial property. Among all the tested microorganisms, the essential oil showed the strongest inhibitory effect against $S$. typhimurium. The data of this study suggests that the essential oil from Radix aucklandiae has great potential for application as a natural antimicrobial agent to preserve food.
\end{abstract}

\section{Keywords}

Radix aucklandiae, Essential Oil, GC-MS, Antibacterial Activity

\section{Introduction}

In recent years, the number of reported cases of infectious diseases, especially those caused by microbial con-

${ }^{*}$ Corresponding author.

How to cite this paper: Liu, J.X., Huang, D.F., Hao, D.L. and Hu, Q.P. (2014) Chemical Composition, Antibacterial Activity of the Essential Oil from Roots of Radix aucklandiae against Selected Food-Borne Pathogens. Advances in Bioscience and Biotechnology, 5, 1043-1047. http://dx.doi.org/10.4236/abb.2014.513119 
tamination of foods, has been increased dramatically throughout the world [1]. The contamination of raw and/or processed foods with microflora can take place at various stages from production to sale and distribution. Various microorganisms such as Staphylococcus aureus, Bacillus subtilis, Salmonella typhi, Pseudomonas aerugionsa and Escherichia coli may lead to food spoilage, one of the most important concerns of the food industry [2]. Many attempts, such as use of synthetic chemicals, have been made to control microbial growth and to reduce the incidence of food poisoning and spoilage with antimicrobial chemicals. With the increased focus on food safety issues, consumers have been more sensitive to the chemical synthesis of spices and preservatives. The demand for less use of synthetic preservatives has led to research and use of "naturally derived" antimicrobials [3]. Some natural substances of plant origin have good antimicrobial properties and have been used as seasonings for centuries. One such possibility is the use of essential oils as antibacterial additives. Researches reported that the essential oils extracted from many species of plants have potent activity against microorganisms [4].

Recently, there has been an increasing interest in essential oils as potential source of natural and safe antioxidants for food industry. Radix aucklandiae, known as Muxiang in Chinese, is derived from the dried root of Aucklandia lappa Dence, belonging to the family Asteraceae. It is one of the commonly used traditional Chinese medicines which is listed in Chinese Phaemacopoeia [5]. In Chinese Phaemacopoeia, as the makers to control herb quality, the total content of costunolide and dehydrocostuslactone was no less than $1.8 \%$. In recent years, researches on Radix aucklandiae have been mainly focused on the chemical constituent and pharmacology. However, there is no literature available for the antibacterial and antioxidant of main constituents in Radix aucklandiae. The information are still limited to our knowledge; little work has been reported on the antioxidant and antibacterial properties of extracts from Radix aucklandiae as well as action mechanism on the growth of food-borne pathogens. Therefore, the aim of the present study was conducted to investigate antibacterial activity and ingredient of essential oil on several food related bacteria and to further evaluate the possible mechanism of action.

\section{Materials and Methods}

\subsection{Plant Materials}

Dried $R$. aucklandiae were purchased from the Beijing TongRenTang drugstore and stored in deep freeze at $-20^{\circ} \mathrm{C}$ until analysis.

\subsection{Chemicals}

Nutrient agar (NA) and nutrient broth (NB) were from Beijing Aoboxing Bio-tech Co. Ltd. (Beijing, China). Other chemicals used were all of analytical grade.

\subsection{Microbial Strains and Culture}

The antibacterial activity was tested against six different microorganisms. Three Gram-positive strains were $S$. aureus ATCC 25923, S. albus ATCC 8799, and B. subtilis ATCC 6051. Three Gram-negative bacteria were $S$. typhimurium ATCC 19430, S. dysenteriae CMCC (B) 51252 and E. coli ATCC 25922. The strains were provided by the College of Life Science, Shanxi Normal University, and cultured at $37^{\circ} \mathrm{C}$ on NA or NB mediums.

\subsection{Extraction of Essential Oil}

The dried R. aucklandiae (500 g) was ground with a micro plant grinding machine and hydro distilled for $4 \mathrm{~h}$ using a Clevenger-type apparatus [6]. The oil was separated from water and dried over anhydrous sodium sulfate and stored in tightly closed dark vials at $4^{\circ} \mathrm{C}$ until use. The essential oil was obtained as a bright yellow transparent liquid and had specific $R$. aucklandiae aroma.

\subsection{GC-MS Analysis}

The analysis of the essential oil was performed using a Hewlett-Packard 5890 II GC, equipped with a HP-5 MS capillary column ( $30 \mathrm{~m} \times 0.25 \mathrm{~mm}$; film thickness, $0.25 \mu \mathrm{m}$ ) and a HP 5972 mass selective detector for the separation. The mass selective detector was operated in electron-impact ionization (EI) mode with a mass scan 
range from $\mathrm{m} / \mathrm{z} 50$ to 550 at $70 \mathrm{eV}$. GC conditions were the same as described above. The components were identified by comparing their GC retention indices, NIST mass spectral search program (version 2.0, National Institute of Standards and Technology), and mass spectra with publish data.

\subsection{Antibacterial Activity}

The essential oil was dissolved in ethanol and the concentration tested was $50 \%$, and then sterilized by filtration through $0.22 \mu \mathrm{m}$ Millipore filters. Antimicrobial tests were then carried out by the Oxford cup method using 200 $\mu \mathrm{L}$ of suspension containing $1 \times 10^{6}$ colony forming units $(\mathrm{CFU}) / \mathrm{mL}$ of bacteria spread on nutrient agar (NA) medium. Oxford cups (6 mm in diameter) were placed on the inoculated agar, and then $200 \mu \mathrm{L}$ of essential oil was added with a micropipette [7]. The diameter of inhibition zone (DIZ) was measured after $24 \mathrm{~h}$ of incubation at $37^{\circ} \mathrm{C}$. Ethanol was used as negative control, respectively. Tests were performed in triplicate.

\subsection{Minimum Inhibitory Concentration (MIC) and Minimum Bactericide Concentration (MBC) Assay}

MIC and MBC were determined according to the method described by Diao et al. with minor modifications [7]. Briefly, stock solution of the essential oil was prepared in ethanol. Two fold serial dilutions of essential oil were filtered through $0.22 \mu \mathrm{m}$ Millipore filters and prepared in sterile NB medium ranging from 0.3125 to $5 \mathrm{mg} / \mathrm{mL}$. To each tube $50 \mu \mathrm{L}$ of the exponentially growing bacterial cells was added into medium, and the cell concentration in each medium was approximately $1 \times 10^{6} \mathrm{CFU} / \mathrm{mL}$. A control test was also performed containing inoculated broth supplemented with only ethanol. The maximum final concentration of ethanol in each medium was $2 \%$, which did not have effect on the growth of the tested strains. The tubes were then incubated at $37^{\circ} \mathrm{C}$ for $24 \mathrm{~h}$ and examined for evidence of the growth. The MIC was determined as the lowest concentration of the essential oil that demonstrated no visible growth. The MBC was determined as follows. After the determination of the MIC, 100 -fold dilutions with drug-free NB from each tube showing no turbidity were incubated at $37^{\circ} \mathrm{C}$ for $48 \mathrm{~h}$. The MBC was the lowest concentration of the essential oil that showed no visible growth in the drug-free cultivation. All experiments were performed in triplicate.

\subsection{Statistical Analysis}

All results are expressed as mean \pm SD $(n=3)$. In order to evaluate the significant differences between sample means, one-way analysis of variance (ANOVA) and Duncan's test were performed with significant level being considered at $p<0.05$.

\section{Results}

\subsection{Chemical Composition of the Essential Oil}

The chemical composition of the essential oil was analyzed by GC-MS and the result was presented in Table 1. In total, 23 components were identified, representing $57.95 \%$ of the total amount, eremanthin (12.74\%) was found as the main component. d-Guaiene (6.26\%) was the second major componment detected in Radix aucklandiae oil, followed by $\zeta$-Himachalene (6.16\%), l-Caryophyllene (4.84\%), and others were found to be the minor components in the essential oil of Radix aucklandiae. The profile obtained in the present study was differences to the previous results reported. This paper detected eremanthin in the main content, however, there have been reported in the literature, the chemical constituents of volatile oil in Radix aucklandiae, The main ingredient is Alantolactone. Because the Radix aucklandiae volatile oil composition is complex, and because of different origin, there are the obvious differences.

\subsection{DIZ, MIC and MBC of the Essential Oil}

The DIZ, MIC, and MBC values of the essential oil from Radix aucklandiae are presented in Table 2. The results showed that the essential oil had a gratifying antibacterial activity on all of the tested food-borne pathogens, including both Gram-positive and Gram-negative bacteria. The DIZ values for all tested bacterial strains were in the range of 12.85 - $24.95 \mathrm{~mm}$. The DIZ was the maximum value for $S$. typhimurium, the minimum value for $S$. albus. In contrast with above strains, although the DIZ values were lower for S. albus, we can not deny that the 
Table 1. Chemical composition of essential oil from Radix aucklandiae.

\begin{tabular}{|c|c|c|c|}
\hline Time & Chemical formula & Compounds & Reak area (\%) \\
\hline 9.74 & $\mathrm{C}_{10} \mathrm{H}_{16}$ & 3-Carene & 0.02 \\
\hline 11.6 & $\mathrm{C}_{10} \mathrm{H}_{16}$ & 2-Pinene & 0.14 \\
\hline 14.13 & $\mathrm{C}_{10} \mathrm{H}_{18} \mathrm{O}$ & Cineole & 0.01 \\
\hline 21.13 & $\mathrm{C}_{10} \mathrm{H}_{18} \mathrm{O}$ & 4-Carvomenthenol & 0.04 \\
\hline 30.33 & $\mathrm{C}_{15} \mathrm{H}_{24}$ & Beta-neoclovene & 0.26 \\
\hline 30.83 & $\mathrm{C}_{15} \mathrm{H}_{24}$ & d-Guaiene & 6.26 \\
\hline 31.83 & $\mathrm{C}_{15} \mathrm{H}_{24}$ & g-Elemene & 3.88 \\
\hline 31.97 & $\mathrm{C}_{15} \mathrm{H}_{24}$ & Longifolene & 4.84 \\
\hline 32.25 & $\mathrm{C}_{13} \mathrm{H}_{20} \mathrm{O}$ & Ionone & 1.90 \\
\hline 32.50 & $\mathrm{C}_{15} \mathrm{H}_{24}$ & cis,trans-a-Farnesene & 1.06 \\
\hline 33.21 & $\mathrm{C}_{15} \mathrm{H}_{24}$ & a-Caryophyllene & 0.98 \\
\hline 34.57 & $\mathrm{C}_{15} \mathrm{H}_{22}$ & a-Curcumenea & 5.40 \\
\hline 34.64 & $\mathrm{C}_{15} \mathrm{H}_{24}$ & Beta-neoclovene & 4.32 \\
\hline 35.02 & $\mathrm{C}_{15} \mathrm{H}_{24}$ & Neocloven & 3.16 \\
\hline 35.40 & $\mathrm{C}_{15} \mathrm{H}_{24}$ & g-Gurjunene & 1.32 \\
\hline 35.74 & $\mathrm{C}_{15} \mathrm{H}_{24}$ & Aristolene & 0.90 \\
\hline 37.12 & $\mathrm{C}_{15} \mathrm{H}_{24}$ & Caryophyllene-(II) & 0.80 \\
\hline 38.50 & $\mathrm{C}_{15} \mathrm{H}_{24} \mathrm{O}$ & a-Santalol & 2.66 \\
\hline 45.49 & $\mathrm{C}_{15} \mathrm{H}_{24}$ & 8-Cedren-13-ol & 6.16 \\
\hline 49.34 & $\mathrm{C}_{15} \mathrm{H}_{22} \mathrm{O}_{2}$ & b-Guaiene & 0.40 \\
\hline 50.76 & $\mathrm{C}_{15} \mathrm{H}_{18} \mathrm{O}_{2}$ & Eremanthin & 12.74 \\
\hline 51.37 & $\mathrm{C}_{20} \mathrm{H}_{36} \mathrm{O}_{2}$ & 9,12-Octadecadienoic acid (Z,Z)-, ethyl ester & 0.36 \\
\hline 51.89 & $\mathrm{C}_{18} \mathrm{H}_{30} \mathrm{O}_{2}$ & Linolenic acid & 0.34 \\
\hline
\end{tabular}

Table 2. DIZ, MIC, and MBC of the essential oil from Radix aucklandiae.

\begin{tabular}{lccc}
\hline \multicolumn{1}{c}{ Microorganisms } & DIZ $^{\mathrm{a}}(\mathrm{mm})$ & $\mathrm{MIC}(\mathrm{mg} / \mathrm{mL})$ & $\mathrm{MBC}(\mathrm{mg} / \mathrm{mL})$ \\
\hline Gram-positive & & & 5 \\
$\quad$ S. aureus & $18.55 \pm 0.49 \mathrm{~b}$ & 1.25 & 5 \\
S. albus & $12.85 \pm 0.07 \mathrm{c}$ & 1.25 & 2.5 \\
B. subtilis & $19.75 \pm 1.06 \mathrm{~b}$ & & 2.25 \\
Gram-negative & & 1.25 & 1.25 \\
S. typhimurium & $24.95 \pm 0.63 \mathrm{a}$ & 1.25 & 2.5 \\
S. dysenteriae & $15.00 \pm 0.71 \mathrm{bc}$ & 1.25 & \\
E. coli & $16.45 \pm 0.49 \mathrm{bc}$ &
\end{tabular}

${ }^{\mathrm{a}}$ Values represent means of three independent replicates \pm SD. Different letters within a column indicate statistically significant differences between the means $(p<0.05)$.

essential oil from Radix aucklandiae had a better antibacterial activity on these food-borne pathogens because the DIZ values were much higher than that of negative control. The MIC and MBC values for tested bacterial strains were in the range of $1.25 \mathrm{mg} / \mathrm{mL}$ and 1.25 - $5.0 \mathrm{mg} / \mathrm{mL}$, respectively. Gram-positive bacteria, the essential oil from Radix aucklandiae performed larger DIZ and lower MIC against three strains which indicated it was more effective bacterial inhibitor and bactericide against B. subtilis. Among Gram-negative bacteria, there were significant differences in DIZ and MBC values. At the mean time, S. typhimurium was the most common Gram-negative food borne pathogens. Therefore, the antibacterial properties and action mechanism of essential 
oil from seeds against B. subtilis and S. typhimurium will be further investigated in this study.

\section{Discussions and Conclusions}

The eremanthin was found to be the major compounds of essential oil from costustoo by GC-MS analysis, which was a new constituent.

The antibacterial activity of the essential oil and plant extracts of Radix aucklandiae has not been studied up to now. However, the essential oil or extracts of some members of the Compositae family, such as Artemsia argyi and eupatorium [8] was previously reported. The results from the Oxford cup method, followed by measurements of MIC and MBC indicated that the essential oil from Radix aucklandiae had strong and consistent inhibitory effect against all of the tested food-borne pathogens including both Gram-positive and Gram-negative bacteria as confirmed by the inhibitory effect of the essential oil showing different susceptibility rate against the tested food-borne pathogens, and S. typhimurium was found to be the most sensitive microorganisms tested, showing larger inhibition zone and lower MIC and MBC values.

Based on the present research, the essential oil from Radix aucklandiae, which is rich in eremanthin, possesses good antibacterial activity against selected food-borne pathogens in this study. Therefore, further research on the chemical compositions, mechanisms of action, the toxicological effect as well as the effects of from Radix aucklandiae on other food spoilage and poisoning bacteria is still necessary to fully evaluate the potential of Radix aucklandiae in foods and medicines. At the same time it provides a theoretical basis for the study of Compositae plant essential oils.

\section{Acknowledgements}

This work was financially supported by a Program for the Top Young Academic Leaders of Higher Learning Institutions of Shanxi, and a Project of the Natural Science Foundation of Shanxi Province, China (project no. 2012011031-3).

\section{References}

[1] Gulluce, M., Sahin, F., Sokmen, M., Ozer, H., Daferera, D., Sokmen, A., Polissiou, M., Adiguzel, A. and Ozkan, H. (2007) Antimicrobial and Antioxidant Properties of the Essential Oils and Methanol Methanol from Mentha longifolia L. ssp. lingifolia. Food Chemistry, 103, 1449-1456. http://dx.doi.org/10.1016/j.foodchem.2006.10.061

[2] Sokmen, A., Gulluce, M., Akpulat, H.A., Daferera, D., Tepe, B., Polissiou, M., Sokmen, M. and Sahin, F. (2004) The in Vitro Antimicrobial and Antioxidant Activities of the Essential Oils and Methanol Extracts of Endemic Thymus spathulifolius. Food Control, 15, 627-634. http://dx.doi.org/10.1016/j.foodcont.2003.10.005

[3] Goncalves, M.J., Cruz, T.M., Cavaleiro, C., Lopes, M.C. and Salgueiro, L. (2010) Chemical, Antifungal and Cytotoxic Evaluation of the Essential Oil of Thymus zygis subsp. Sylvestris, Industrial Crop and Products, 32, 70-75. http://dx.doi.org/10.1016/j.indcrop.2010.03.005

[4] Ameur, E., Karima, H.S., Samia, M., Khouja, M.L., Rachid, C. and Fethia, H. (2011) Antibacterial Activity and Chemical Composition of 20 Eucalyptus Species’ Essential Oils. Food Chemistry, 129, 1427-1434. http://dx.doi.org/10.1016/j.foodchem.2011.05.100

[5] Zhang, J., Hu, X., Gao, W., Qu, Z., Guo, H., Liu, Z. and Liu, C. (2014) Pharmacokinetic Study on Costunolide and Dehydrocostuslactone after Oral Administration of Traditional Medicine Aucklandia Lappa Decne by LC/MS/MS. Journal of Ethnopharmacology, 151, 191-197. http://dx.doi.org/10.1016/j.jep.2013.10.024

[6] Viuda-Martosa, M., Mohamady, M.A., Fernández-López, J., ElRazik, K.A.A., Omer E.A., Pérez-Alvarez, J.A. and Sendra, E. (2011) In Vitor Antioxidant and Antibacterial Activities of Essentials Oils Obtained from Egyptian Aromatic Plants. Food Control, 22, 1715-1722. http://dx.doi.org/10.1016/j.foodcont.2011.04.003

[7] Diao, W., Hu, Q., Zhang, H. and Xu, J. (2014) Chemical Composition, Antibacterial Activity and Mechanism of Action of Essential Oil from Seeds of Fennel (Foeniculum vulgare Mill.). Food Control, 35, 109-116. http://dx.doi.org/10.1016/j.foodcont.2013.06.056

[8] Gao, C., Tian, C., Lu, Y., Xu, J., Luo, J. and Guo, X. (2011) Essential Oil Composition and Antimicrobial Activity of Sphallerocarpus gracilis Seeds against Selected Food-Related Bacteria. Food Control, 22, 517-522. http://dx.doi.org/10.1016/j.foodcont.2010.09.038 
Scientific Research Publishing (SCIRP) is one of the largest Open Access journal publishers. It is currently publishing more than 200 open access, online, peer-reviewed journals covering a wide range of academic disciplines. SCIRP serves the worldwide academic communities and contributes to the progress and application of science with its publication.

Other selected journals from SCIRP are listed as below. Submit your manuscript to us via either submit@scirp.org or Online Submission Portal.
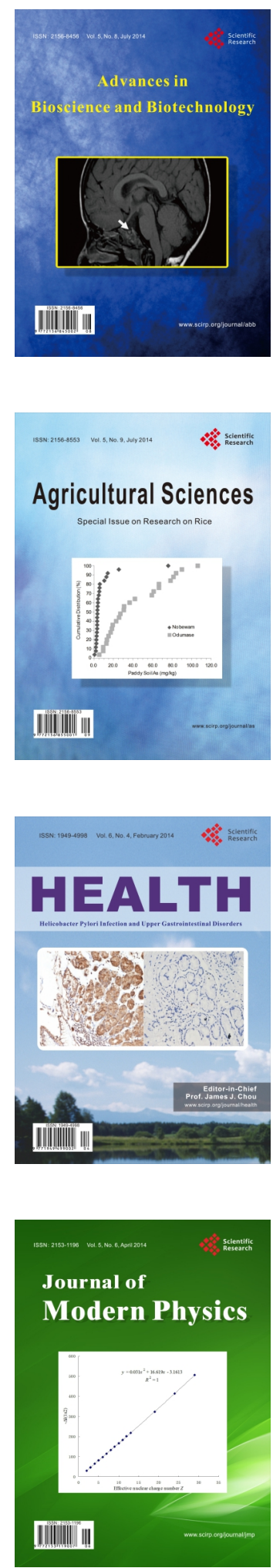
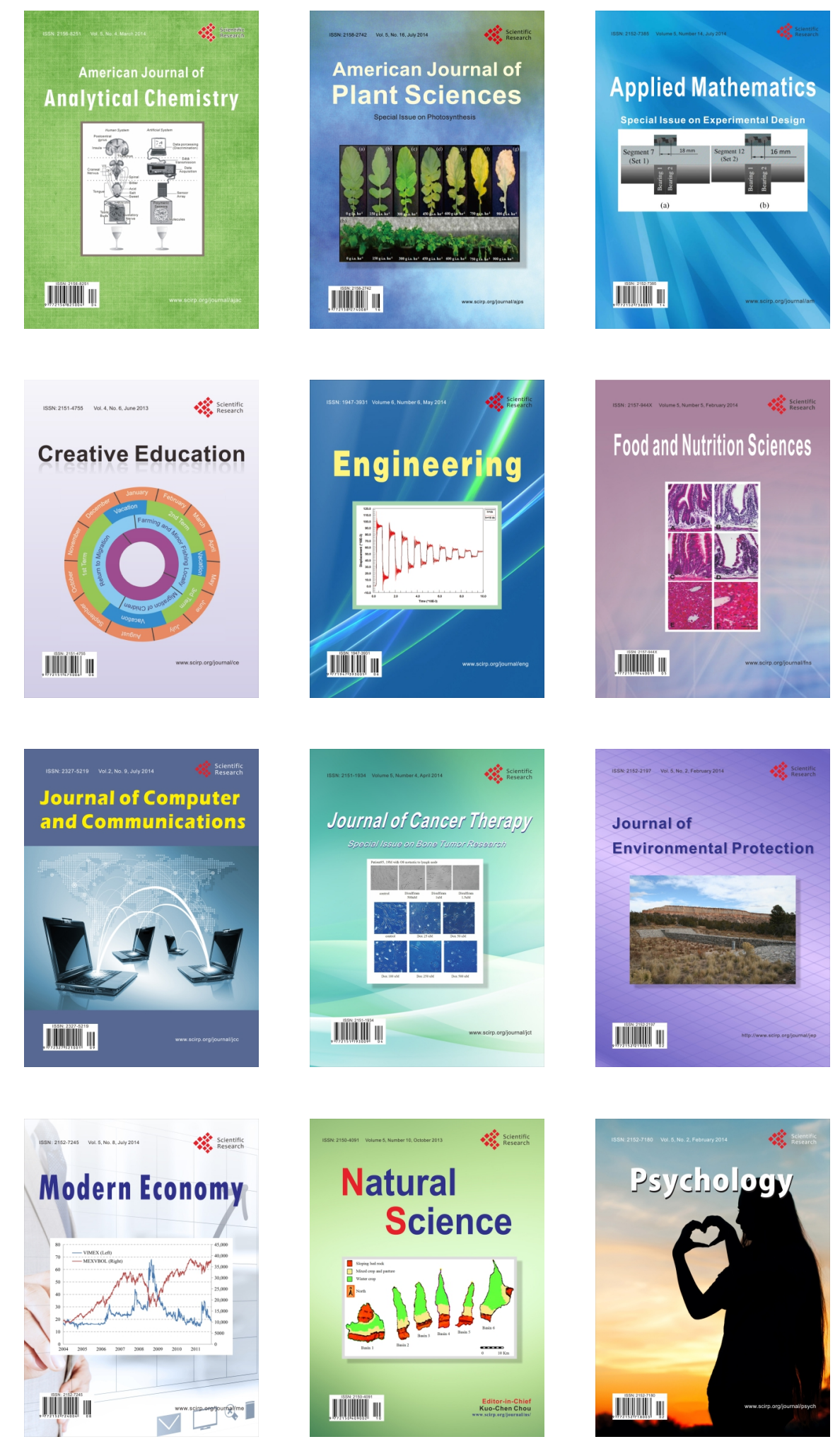